\title{
Examining the link between HRM Practices and Employees' Performance in Nigerian public sector
}

\author{
Abubakar Tabiu*, Faizuniah Pangil and Siti Zubaidah Othman
}

School of Business Management, Universiti Utara Malaysia (UUM)

\section{H R O N I C L E \\ A B S T R A C T}

Article history:

Received February 5, 2016

Improving employee and organizational performance has been the main concern of many

Received in revised format April organizations for decades and several factors have also been studied as predictors of employee 15,2016

Accepted April 20, 2016

Available online

April 25, 2016

Keywords:

Task performance

Contextual performance

Adaptive performance

HRM practices

\section{Introduction}

In order to successfully attain their goals and achieve competitive advantage, organizations required the contributions of highly performing individuals (employees), so as to deliver the products and services they specialized in (Sonnentag \& Frese, 2002). However, the performance of public sector employees in the developing country like Nigeria is characterized by poor attitude to work (Suleiman, 2013), inefficiency (Obasanjo, 2003), declining standard on the provision of public goods and services both in terms of quality and quantities (Salisu, 2001). These problems led to public outcry that made government to establish several public service reform measures such as public service reform of 19972007 and 2010-2013 among others. These reforms introduces SERVICOM (An agency established to ensure that citizens enjoyed efficient and effective goods and service delivery), reviewing the public service organizational structures, rationalizing ministries and departments with the aim of improving the performance of employees for optimum service delivery and enhance their efficiency and effectiveness. But still, as recently argued by Inyang and Akaegbu (2014), designing and implementing

\footnotetext{
* Corresponding author.

E-mail address: abubakartabiu@yahoo.com (A. Tabiu) 
effective human resource management (HRM) strategies and practices is highly needed to facilitate the development of effective, competent and highly performing workforce in the public sector.

Literature on employee performance revealed that several factors at organizational levels, individual levels and job related factors are the main factors that predict employee performance in organization (Barrick et al., 2001; Cote \& Miners, 2006; Pushpakumari, 2008). Some of the job related factors studied to date includes: job stress (Chen, 2009; Yozgat et al., 2013), job satisfaction (Perera et al., 2014; Pushpakumari, 2008; Wright et al., 2007), job experience (Kolz et al., 1998; Kotur \& Anbazhagan, 2014). While some of the individual factor studies includes: commitment (Memari, Mahdieh, \& Marnani, 2013; Susanty et al., 2013), personality (Abdullah et al., 2013; Rothmann \& Coetzer, 2003), engagement (Anitha, 2014), emotional intelligence (Kumar, 2014; Shooshtarian et al., 2013).

Nevertheless, majority of these studies operationalized employee performance as unidimensional construct. Despite, the arguments of both earlier scholars (Borman \& Motowidlo, 1993; Campbell, 1990; Murphy, 1989; Tsui et al., 1997) and recent scholars (Demortier et al., 2014; Fluegge, 2008; Koopmans et al., 2011), that performance at individual level is multi-dimensional construct. This clearly indicated that studies that operationalized employee performance as unidimensional construct had not comprehensively captured the real measurement of employee performance. In this regard, Borman, Klimoski, and Ilgen (2003) argued that each of these three aspect of employee performance (task, contextual and adaptive performance) provided unique contribution toward enhancing organizational effectiveness. For instance, if an employee in a given organization exhibit exceptional regard on task performance but fail to exhibit contextual performance (like cooperating with or assisting other employees) the organizational effectiveness will suffer. Similarly, higher level of task related performance alone without adaptive performance may likely cause stagnation over a period of time or may led to inability to coup with changes thereby leading to deterioration of the overall performance and organizational effectiveness. To address this, the present study attempted to fill this gap by looking at the multi-dimensional nature of employee performance comprehensively. Drawing upon social exchange theory (Blau, 1964), the present study use empirical data from public sectors. The sector that received less attention compared to private sector (Safdar, 2011).

\section{Literature review}

\subsection{Employee performance}

Employee performance simply refers to behaviors of an individual (employee) that can make a significant difference to the organizational goal accomplishment (Motowidlo, 2003). This indicated that employee performance is the expected value of what people do in organizations which are relevant towards enhancing organizational effectiveness. For the purpose of this study, three dimensions of employee performance that enhance organizational effectiveness are considered. They include: task performance, contextual performance and adaptive performance (Allworth \& Hesketh, 1999; Borman \& Motowidlo, 1993; Koopmans et al., 2012). Task performance is defined by Borman and Motowidlo, (1993) 'as the effectiveness with which employee (job incumbents) perform activities or behaviors that contribute towards achieving the organization's technical core (objectives) either directly by carrying out a part of its technological process, or through indirect ways by providing the needed services or materials. For instance, when fire fighter performs a rescue operation he/she had performed task performance (Borman \& Motowidlo, 1993; Borman \& Motowidlo, 1997). Similarly, Borman and Motowidlo (1993) conceptualized contextual performance "as individual behaviors that support the organizational, social, and psychological environment in which the technical core must function".

Contextual performance encompassed behaviors of employees that are not within the required job description but still promotes organizational effectiveness. On the other hand, adaptive performance as the third dimension of employee performance refers to the level to which an individual employee(s) adapts to changes in the work environment (Griffin, Neal, \& Parker, 2007). Thus, it is an aspect of 
employee performance that reflects acquiring and enhancing competencies in response to different changes in organization.

\subsection{HRM Practices}

HRM practices as a concept have been defined by different scholars in many ways. Schuler and Jackson (1987), defined HRM practices as the organizational activities directed at managing the employees and ensuring that these resources (employees) are utilized towards the attaining organizational goals. Similarly, Delery and Doty (1996) conceptualized HRM practices as set of policies and practices specifically designed and executed to ensure that organizations' employees (human capital) contribute toward the attainment of organizational objectives. Simply put, building on the above definitions, HRM practices comprises set of specific practices, philosophies and formal policies, designed by organizations to attract, motivate, develop, and retain human resource (employees) for effective functioning of the organization.

\subsection{HRM practices and employee performance}

This section provides the link between all the six HRM practices (job rotation, training, compensation, job autonomy, communication and career planning) and employee task, adaptive and contextual performance.

\subsubsection{Job rotation and employee performance}

The HRM practice of moving employees to work at different tasks or positions within the organization for a given periods of time in a planned ways through lateral transfers that allowed employees to acquire a range of knowledge skills, and competencies is called Job rotation (Jorgensen et al., \& Dunning, 2005). Job rotation provided employees with the opportunities to learn multiple skills, knowledge and outlooks (Eguchi, 2005). Previous studies indicates a positive link between job rotation and employee performance in private sector organizations (Hosseini et al., 2015; Khan et al., 2014). They argued that adoption of effective job rotation practice in organization brings positive employee performance. In addition, Rashki et al. (2014) revealed that lateral transfer of employee from one duty post to another within the organization significantly promote high employee performance. The above findings gave rise to our first hypothesis:

H1a: Job rotation positively relates to task performance,

H1b: Job rotation positively relates to contextual performance,

H1c: Job rotation positively relates to adaptive performance.

\subsubsection{Training and Employee Performance}

Latham (1988) defined training \& development as "the systematic process of acquiring and development of the knowledge, skills, and attitudes that are required by the employees to adequately perform a given task or job or to improve performance in their job environment". Training allows employees to initiates the development of new skills and behaviors coupled with the motivation to apply those skills and behaviors in their task and contextual activities at work (Sels, 2002; Way, 2002). Prior research has demonstrated the influence of training on employee performance (Jagero, Komba, \& Mlingi, 2012; Nadarasa, 2013; Tabiu \& Nura, 2013; Tiwari, 2011). Extant empirical research has shown that training had a significant positive relation with employee performance (Amin et al., 2013; Khan \& Jabbar, 2013; Sultana et al., 2012). In addition, the study conducted by Dysvik and Kuvaas (2008), established that training opportunities is positively significant with both task performance and contextual performance in Norwegian service organizations. Based on these arguments and empirical evidences above the following hypotheses are advanced. 
H2a: Training is positively related to task performance.

$\mathrm{H} 2 \mathrm{~b}$ : Training is positively related to contextual performance.

H2c: Training is positively related to adaptive performance

\subsubsection{Compensation and Employee Performance}

Compensation simply refers to total amount of rewards (both the financial and the nonfinancial) that organizations/companies give employees in return for work performed (Williams, 2008). Management and employee always views both financial and the nonfinancial rewards as motivator of performance improvement (Nadarajah et al., 2012). Shahzad et al. (2008) supported that good compensation scheme that comprises both financial and non financial rewards motivate employees to work harder and show high competencies towards achieving organizational objectives. Compensation is also considered to be one of the key factors that could influence the performance of employee (Vlachos, 2009). Empirical studies on the relationship between compensation and employee performance revealed that compensation positively relates with employee performance (Baloch et al., 2010; Marwat et al., 2006; Shahzad et al., 2008). They supported that adequate compensation package encourage employees towards higher task, contextual and adaptive performance. This led to our third hypotheses:

H3a: Compensation is positively related to task performance.

$\mathrm{H} 3 \mathrm{~b}$ : Compensation is positively related to contextual performance.

$\mathrm{H} 3 \mathrm{c}$ : Compensation is positively related to adaptive performance

\subsubsection{Job autonomy and Employee Performance}

Job autonomy as HRM practice allows employees substantial discretion and freedom in the determination of ways and procedure to be followed in conducting their assigned job in organization (Hackman \& Oldham, 1975). Langfred and Moye (2004) argued that job autonomy practice enhances employee performance as in make the employees to perceive that they are more capable of performing assigned task. In a similar way, Huang (2015) supported that employee performance increases when employees enjoyed more autonomy and discretion in organization. Findings from the study of Cho and Yoon (2009), supported positive influence of autonomy on employee performance in the context of Korean public service. Similarly, Gellatly and Irving (2001), found positive relationship between autonomy and contextual performance. Based on these the forth hypothesis is formulated:

H4a: Job autonomy is positively related to task performance.

$\mathrm{H} 4 \mathrm{~b}$ : Job autonomy is positively related to contextual performance.

H4c: Job autonomy is positively related to adaptive performance

\subsubsection{Communication and Employee Performance}

Communication as HRM practice refers to the process of exchanging information in organization from one person (employee) to another, via understandable signals or symbols (Leković \& Berber, 2014). Good communication practice (both upward and downward) increases employee confidence level and trust leading to more positive performance. Gray and Laidlaw (2002) opined that effective communication practice led to more positive work consequences in organization. For instance, when employees enjoyed appropriate communication in their organization like receiving timely and adequate feedback information, been kept well informed of changes etc., then favorable organizational outcomes from such employees would be expected. Moreover, empirical study from Muda, Rafiki, and Harahap (2014), revealed that communication practice significantly influence employee performance in Indonesian Islamic Banks. This was in line with the findings of Chen, Silverthorne, and Hung (2006), 
that also revealed communication led to higher levels of employee performance among accounting professional in America and Taiwan. Additionally, the recent study of Asamu (2014) established positive relationship between effective communication and employee performance in Nigeria. These led to the following hypotheses:

H5a: Communication is positively related to task performance.

H5b: Communication is positively related to contextual performance.

H5c: Communication is positively related to adaptive performance.

\subsubsection{Career planning and Employee Performance}

Career planning refers to the HRM practice of aligning the employee's interests, skills and knowledge with the organizational needs with aim of attaining proper individual and organizational goals. Previous empirical studies of Tiwari (2011) and Marwat et al. (2006) revealed that career planning is an important predictor of employee performance in organization. Additionally, Khalid et al. (2014) and Cho and Yoon (2009) supported that employee mostly seek employment and give their best in organizations that offer good career planning and opportunities for advancement. This implied that employees prefer to remain and work in organizations that care and plan for their careers and in return perform optimally in terms of task, contextual and adaptive behaviours. Based on the above arguments, our last hypotheses are formulated:

H6a: Career planning is positively related to task performance.

H6b: Career planning is positively related to contextual performance.

H6c: Career planning is positively related to adaptive performance.

\section{Research Framework}

Based on the hypotheses developed and the theoretical explanation, a research framework was developed. As shown in Fig. 1, it is expected that the six HRM practices can significantly influence positive employee task, contextual and adaptive performance.

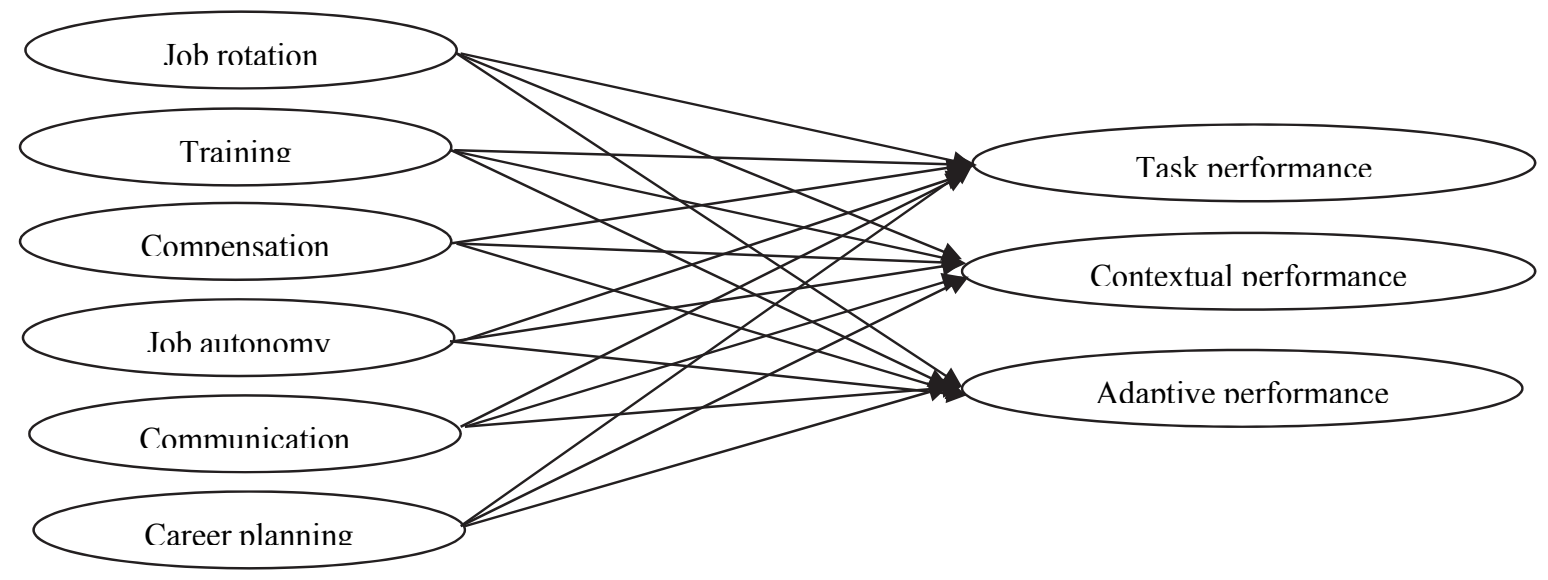

Fig. 1. Research framework 


\section{Method}

\subsection{Research Design}

This study employed a quantitative research design as the study is interested in exploring the relationships between employees' perception of HRM practices and self-report employee performance. Data was analyzed using SPSS and Smart PLS method (Ringle, Wende, \& Will, 2005). Questionnaires were personally administered by the researcher to local government employees in northern Nigeria. Additionally, employees were selected in collaboration with the HR staff so as to ensure that the sample truly represent the whole workforce. Employees were also informed about the objective of the study and its confidentiality. Participants are encouraged to participate in the survey and two weeks was given to them to complete and submit back the questionnaires.

\subsection{Participants}

The participants are 265 senior staff of local government in the north western region of Nigeria. Majority of the participant 244 (92.1\%) are male, while the remaining 21(7.9\%) are female. Based on age, $48(18.1 \%)$ are between 19-25 years, $74(27.9 \%)$ are between 26-35 years, $95(35.8 \%)$ are between $36-45$ years, $46(17.4 \%)$ are within the range of 46-55 years and lastly $2(0.8 \%)$ are 56 and above years. The description of participant also indicates that 43 (15.3\%) are single, $229(81.5 \%)$ are married and 9 (3.2\%) fall under divorced/widowed/separated. The academic qualification of respondents shows that $16(6 \%)$ are certificate holders, $99(37.4 \%)$ had Diploma/NCE, $122(46 \%)$ are Degree/HND holders, $21(7.9 \%)$ had master degrees, $2(0.8 \%)$ are $\mathrm{PhD}$ graduates and $5(1.9 \%)$ acquired other academic qualifications apart from the one listed. In relation to the number of years with the present organization only $9(3.4 \%)$ of the participant work for less than one year, $32(12.1 \%)$ are between 1-3 years, 58 $(21.9 \%)$ spent about 4-7 years and majority of the participants $166(62.6 \%)$ work with the organization for more than 7 years.

\subsection{Measures/Instruments}

In this study, employee performance was measured by task performance, contextual performance and adaptive performance. Task performance is operationalized as the behavior of employees in relation to the quality, quantity and efficiency of the core activities he/she is assigned to perform. Task performance was measured by 11 items adapted from (Tsui et al., 1997). Contextual performance is operationalized as the behavior of employees that are outside job description but enhances the organizational effectiveness. We measured contextual performance with 16 items adapted from Motowidlo and Van Scotter (1994), To measure adaptive performance, 8 items developed by Koopmans et al. (2012) were adapted. Adaptive performance is operationalized as the extent to which an individual employee behavior adapt to the different changes in the work environment (Koopmans et al., 2012).

HRM practices were measured by six independent practices including job rotation, training, compensation, job autonomy, communication and career planning. Job rotation was measured using 11 items from Tarus (2014); Training was measured with 6 items from Lam, Chen, and Takeuchi (2009); Compensation was measured by 6 items from Amin, Ismail, Abdul Rasid, and Selemani (2014); job autonomy was measured using 9 items from Breaugh (1999); communication was measured with 6 items from Den Hartog, Boon, Verburg, and Croon (2013); Career planning was measured with 8 items from Amin et al. (2014).

\section{Results}

Table 1 provides the reliability results of all the study constructs, the average variance extracted (AVE) and the values of $\mathrm{R}^{2}$. 
Table 1

Constructs validity and reliability

\begin{tabular}{lccc}
\hline \multicolumn{1}{c}{ Constructs } & AVE & Composite Reliability & R Square \\
\hline Adaptive Performance & 0.57 & 0.84 & 0.60 \\
Job Autonomy & 0.55 & 0.83 & 0.85 \\
Compensation & 0.59 & 0.86 & \\
Communication & 0.60 & 0.87 & 0.59 \\
Career Planning & 0.56 & 0.80 & \\
Contextual Performance & 0.51 & 0.84 & 0.57 \\
Job Rotation & 0.58 & 0.82 & 0.86 \\
Training & 0.53 & & \\
Task performance & 0.51 & & \\
\hline
\end{tabular}

Note: $A V E=$ Average Variance Extracted

Table 1 showed that all of the constructs had a composite reliability above minimum threshold of 0.70 (Hair Jr, Hult, Ringle, \& Sarstedt, 2014). The reliability ranged from 0.80 to 0.87 . Additionally, all the latent construct had attained AVE above 0.50 as recommended by Hair Jr et al. (2014). Table 1 also showed that $\mathrm{R}^{2}$ for all the three dependent variables had a substantial values based on Cohen (1988) criterion for assessing coefficient of determination (see Fig 2.1 for the PLS algorithm results).

Results of correlations and square roots of AVE of all the latent variables are shown in Table 2.

Table 2

Correlations and square roots of AVE of latent variables

\begin{tabular}{|c|c|c|c|c|c|c|c|c|c|}
\hline Constructs & ADP & AUT & CMP & COM & CPL & CTX & JRT & TRN & TSK \\
\hline Adaptive Performance & 0.76 & & & & & & & & \\
\hline Job Autonomy & 0.51 & 0.74 & & & & & & & \\
\hline Compensation & 0.42 & 0.51 & 0.77 & & & & & & \\
\hline Communication & 0.67 & 0.38 & 0.47 & 0.78 & & & & & \\
\hline Career planning & 0.69 & 0.47 & 0.52 & 0.72 & 0.75 & & & & \\
\hline Contextual Performance & 0.70 & 0.46 & 0.44 & 0.68 & 0.69 & 0.71 & & & \\
\hline Job rotation & 0.64 & 0.27 & 0.40 & 0.73 & 0.68 & 0.66 & 0.76 & & \\
\hline Training & 0.52 & 0.46 & 0.63 & 0.60 & 0.57 & 0.49 & 0.51 & 0.73 & \\
\hline Task Performance & 0.61 & 0.50 & 0.58 & 0.61 & 0.65 & 0.61 & 0.56 & 0.62 & 0.72 \\
\hline
\end{tabular}

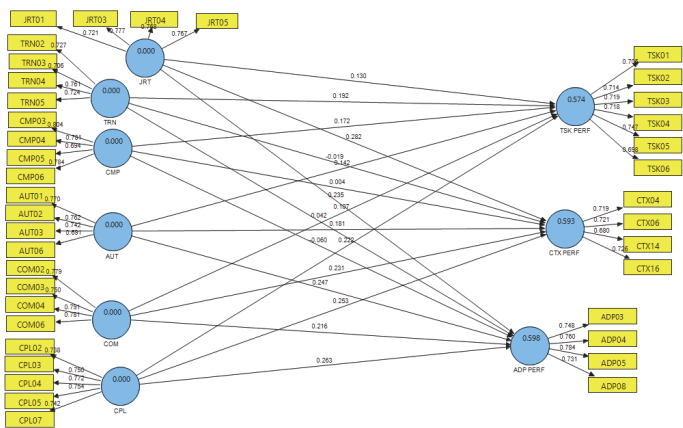

Fig. 2.1 Measurement Model (PLS Algorithm)

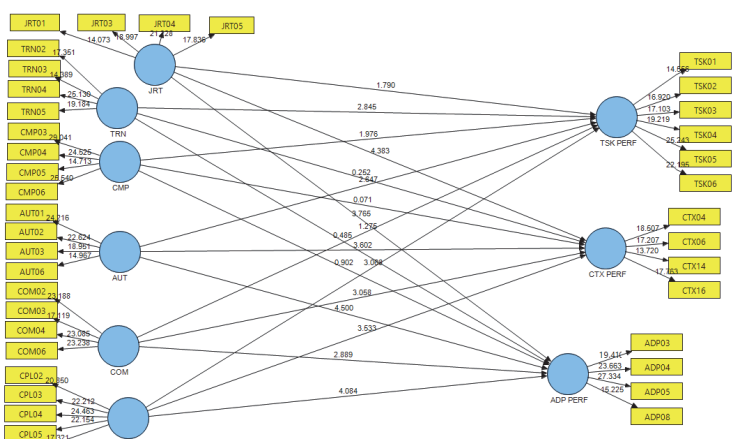

Fig. 2.2. Structural model (PLS bootstrapping)

Fig. 2.1 and 2.2 show the results of PLS algorithm and bootstrapping. As predicted, relationships between job rotation and the three dimensions of employee performance were supported: H1a: Job rotation and task performance $(\beta=0.130 ; \mathrm{t}=1.790 ; \mathrm{p}<0.05) ; \mathrm{H} 1 \mathrm{~b}$ : Job rotation and contextual performance $(\beta=0.282 ; \mathrm{t}=4.383 ; \mathrm{p}<0.01)$; and H1c: Job rotation and adaptive performance $(\beta=0.236$; $\mathrm{t}=3.765 ; \mathrm{p}<0.01)$. However, when training were tested against the three dimensions of employee performance, only training and task performance were found related $(\beta=0.193 ; t=2.845 ; p<0.01)$. This empirical finding gives support to H2a. Similar finding was also obtained when compensation was 
tested against employee performance. Significant positive relationship was only found between compensation and task performance $(\beta=0.172 ; \mathrm{t}=1.976 ; \mathrm{p}<0.05)$. Thus, support hypothesis H3a.

As for autonomy and employee performance, the results indicate that autonomy was related to all dimensions of employee performance; autonomy and task performance $(\beta=0.142 ; t=2.647 ; p<0.05)$, autonomy and contextual performance $(\beta=0.181 ; \mathrm{t}=3.602 ; \mathrm{p}<0.01)$ and autonomy and adaptive performance $(\beta=0.248 ; \mathrm{t}=4.500 ; \mathrm{p}<0.01)$. These findings provide supports for hypotheses $\mathrm{H} 4 \mathrm{a}, \mathrm{H} 4 \mathrm{~b}$ and $\mathrm{H} 4 \mathrm{c}$.

Results from PLS path modeling also show that there are significant positive relationship between communication and contextual performance $(\beta=0.231 ; \mathrm{t}=3.058 ; \mathrm{p}<0.01)$, and between communication practice and adaptive performance $(\beta=0.217 ; \mathrm{t}=2.889 ; \mathrm{p}<0.05)$. Thus, support hypotheses H5b and H5c.

Finally, the current findings show significant positive relationship between career planning and all three employee performance dimensions: career planning and task performance $(\beta=0.222 ; \mathrm{t}=3.068 ; \mathrm{p}$ $<0.01)$, career planning and contextual performance $(\beta=0.253 ; \mathrm{t}=3.533 ; \mathrm{p}<0.01)$, and career planning and adaptive performance $(\beta=0.263 ; \mathrm{t}=4.084 ; \mathrm{p}<0.01)$. These findings provide support for hypotheses H6a, H6b and H6c.

\section{Table 3}

\begin{tabular}{|c|c|c|c|c|c|}
\hline $\mathrm{H}$ & Relationships & Beta & Std. Err & t-value & Decision \\
\hline H1a & Job rotation $->$ Task performance & 0.130 & 0.072 & $1.79 * *$ & Supported \\
\hline $\mathrm{H} 1 \mathrm{~b}$ & Job rotation $->$ Contextual performance & 0.282 & 0.064 & $4.38 * * *$ & Supported \\
\hline $\mathrm{H} 1 \mathrm{c}$ & Job rotation $->$ Adaptive performance & 0.236 & 0.063 & $3.77 * * *$ & Supported \\
\hline $\mathrm{H} 2 \mathrm{a}$ & Training -> Task performance & 0.193 & 0.068 & 2.85 & Supported \\
\hline $\mathrm{H} 2 \mathrm{~b}$ & Training -> Contextual Performance & -0.019 & 0.075 & 0.25 & Not Supported \\
\hline $\mathrm{H} 2 \mathrm{c}$ & Training -> Adaptive Performance & 0.042 & 0.087 & 0.49 & Not Supported \\
\hline $\mathrm{H} 3 \mathrm{a}$ & Compensation $->$ Task performance & 0.172 & 0.087 & $1.98 * *$ & Supported \\
\hline $\mathrm{H} 3 \mathrm{~b}$ & Compensation $->$ Contextual Performance & 0.004 & 0.057 & 0.071 & Not Supported \\
\hline $\mathrm{H} 3 \mathrm{c}$ & Compensation $->$ Adaptive Performance & -0.060 & 0.067 & 0.90 & Not Supported \\
\hline $\mathrm{H} 4 \mathrm{a}$ & Autonomy-> Task Performance & 0.142 & 0.054 & $2.65^{* *}$ & Supported \\
\hline $\mathrm{H} 4 \mathrm{~b}$ & Autonomy-> Contextual Performance & 0.181 & 0.050 & $3.60 * * *$ & Supported \\
\hline $\mathrm{H} 4 \mathrm{c}$ & Autonomy-> Adaptive Performance & 0.248 & 0.055 & $4.50 * * *$ & Supported \\
\hline $\mathrm{H} 5 \mathrm{a}$ & Communication $->$ Task Performance & 0.107 & 0.084 & 1.28 & Not Supported \\
\hline $\mathrm{H} 5 \mathrm{~b}$ & Communication $->$ Contextual Performance & 0.231 & 0.075 & $3.06 * * *$ & Supported \\
\hline $\mathrm{H} 5 \mathrm{c}$ & Communication- $>$ Adaptive Performance & 0.217 & 0.075 & $2.889 * *$ & Supported \\
\hline H6a & Career planning -> Task Performance & 0.222 & 0.072 & $3.07 * * *$ & Supported \\
\hline $\mathrm{H} 6 \mathrm{~b}$ & Career planning $->$ Contextual Performance & 0.253 & 0.072 & $3.53 * * *$ & Supported \\
\hline H6c & Career planning $->$ Adaptive Performance & 0.263 & 0.065 & $4.08 * * *$ & Supported \\
\hline
\end{tabular}

In summary, Table 3 and Figure 2.2 indicated that out of the 18 hypotheses tested, 13 were supported while the remaining 5 were not empirically supported.

\section{Discussions}

The purpose of this study is to develop and test a model on how certain HRM practices can influence employee task, contextual and adaptive performance in the context of public sector organizations.

Task performance is operationalized as the behaviors of employee that are within their job description. The results indicated that all the six HRM practices with exception of communication had significant positive influence on task performance. This clearly supported that when employees perceived that their organization implemented objective lateral transfers from one duty post to another (job rotation), good training opportunities, adequate compensation packages, good career planning and freedom to 
decide on when and how to do their assigned task (job autonomy), then the employees tend to exhibits higher task performance. This finding supported the argument of social exchange theory (Blau, 1964) which is based on reciprocal relationship in social relationships. It is argued that HRM practices in organizational setting serve as signals to employees that their organization recognizes and value them (Alfes et al., 2013; Crossman \& Abou-Zaki, 2003; Kuvaas \& Dysvik, 2010). When organization provided training opportunities, adequate compensation, autonomy, objective rotation of employees, good career planning to its employee, then employees tend to reciprocate with high task performance (Gong et al., 2010; Sun, Aryee, \& Law, 2007). On the contrary, communication was not a predictor of task performance. The possible reason for insignificant relationship is that communication is more of interaction and conveying information among individuals in organization, while task performance required the employees' technical competencies and abilities (Motowidlo \& Van Scotter, 1994). Another possible reason may be related to oath of secrecy (a law that prohibit employees to disclose official information without permission), which control the flow of information among employees.

Furthermore, contextual performance which is conceptualized as the activities of employees that are not within their job description but still enhances organizational effectiveness. Whiles adaptive performance relate to the degree to which an employee adapts to the different changes in his/her work place. In relation to contextual performance and adaptive performance the study supported that four HRM practices including job rotation, job autonomy, communication and career planning are good predictors of contextual performance and adaptive performance respectively. Thus, suggesting that employee's perception on the presence of these practices (job rotation, job autonomy, communication and career planning) provides them with adequate opportunities to demonstrate more positive contextual and adaptive behaviors. For this reason, it is recommended that for organization to attain positive contextual and adaptive performance, these HRM practices should be given the desired attention. As according less attention to these practices may results in less or even poor contextual and adaptive performance which will ultimately led to poor organizational performance. Contrary to expectations, compensation and training practices are not statistically significant with contextual and adaptive performance in this sample. This is an indication that presence of training and compensation practices may not necessarily influence more contextual and adaptive performance. The most likely reason is that in most public organization in Nigeria, the focus of training and compensation is on task performance rather than based on adaptability and training needs (Onah, 2012). Also, most compensation packages do not cover contextual and adaptive activities because they are outside job descriptions (Obisi et al., 2010).

In spite of the fact that, all the HRM practices studied indicated positive relationship with different dimensions of employee performance, interestingly only job rotation, job autonomy and career planning practices demonstrated significant positive influence on all the three dimensions of employee performance (task, contextual and adaptive). Consequently, this established that management should pay more attention particularly on these practices as neglecting them or inability to adopt and pay more attention to them might be among the major reasons for poor performance of employees.

\subsection{Implications of the study}

The current research findings have several implications for both theory and practice. On the theoretical side, this study extends the current literature on HRM practice and employee performance by providing empirical evidence on the relationship between HRM practices and employee task, contextual and adaptive performance. Additionally, the study extends the understanding and influence of social exchange theory (Blau, 1964) in explaining the relationship between HRM practices and employee task, contextual and adaptive performance.

To the managers and practitioners in the public sectors, the application of this model will provide managers with good understanding of which HRM practice to include in order to enhance optimum 
employee performance. For instance, the findings revealed that all the practice with exception of communication need to be considered if the intention of organization is higher task performance. Similarly, job rotation, job autonomy, communication and career planning are the best practice in promoting contextual and adaptive performance. To sum up, the study suggested that management are encourage to embrace HRM practices in order to boost their employees' task, contextual and adaptive performance.

\subsection{Limitations and direction for future study}

Although, this research provided additional supports for understanding the influence of HRM practices in improving and proper management of employee task, contextual and adaptive performance in the context of Nigerian public sector, nevertheless, the study had some limitations. Firstly, the study used only job rotation, training, compensation, job autonomy, communication and career planning. Therefore, the need for further research that will incorporate other HRM practices like recruitment \& selection and employee involvement may be fruitful. As recruitment \& selection practice will allow the organization to employ the best candidates with required skills and expertise. While, the employee involvement practice may integrates and motivate employees towards positive behaviours and performance. Secondly, in this study the participants were senior staff from various local governments located in the North-Western zone of Nigeria. Therefore, in order to generalize the findings, future research that will comprise participants from both federal, state governments and beyond is desirable.

\section{References}

Abdullah, I., Omar, R., \& Rashid, Y. (2013). Effect of Personality on Organizational Commitment and Employees' Performance: Empirical Evidence from Banking Sector of Pakistan. Middle-East Journal of Scientific Research, 17(6), 761-768.

Alfes, K., Truss, C., Soane, E. C., Rees, C., \& Gatenby, M. (2013). The Relationship Between Line Manager Behavior, Perceived HRM Practices, and Individual Performance: Examining the Mediating Role of Engagement. Human Resource Management, 52(6), 839-859. doi: 10.1002/hrm.21512

Allworth, E., \& Hesketh, B. (1999). Construct-oriented Biodata: Capturing Change-related and Contextually Relevant Future Performance. International Journal of Selection and Assessment, 7(2), 97-111.

Amin, A., Rashid Saeed, M., \& Lodhi, R. N. (2013). The Impact of Employees Training On the Job Performance in Education Sector of Pakistan. Middle-East Journal of Scientific Research, 17(9), 1273-1278.

Amin, M., Ismail, W. K. W., Abdul Rasid, S. Z., \& Selemani, R. D. A. (2014). The impact of human resource management practices on performance: Evidence from a Public University. The TQM Journal, 26(2), 125-142.

Anitha, J. (2014). Determinants of employee engagement and their impact on employee performance. International Journal of Productivity \& Performance Management, 63(3), 308-323. doi: 10.1108/IJPPM-01-2013-0008

Asamu, F. F. (2014). The Impact of Communication on Workers' Performance in Selected Organisations in Lagos State, Nigeria. Journal of humanities and social science, 19(5), 75-82.

Baloch, Q. B., Ali, N., Kiani, T. S., Ahsan, A., \& Mufty, A. (2010). Relationship between HR Practices and Perceived Employees' Performance of Bankers in NWFP, Pakistan (An Empirical Evidence). European Journal of Social Sciences, 18(2), 210-214.

Barrick, M. R., Mount, M. K., \& Judge, T. A. (2001). Personality and performance at the beginning of the new millennium: What do we know and where do we go next? International Journal of Selection and Assessment, 9(1-2), 9-30.

Blau, P. M. (1964). Exchange and power in social life. New York: Transaction Publishers. 
Borman, W. C., Klimoski, R. J., \& Ilgen, D. R. (2003). Stability and change in industrial and organizational psychology. In I. B. Weiner (Ed.), Handbook of psychology (Vol. 12, pp. 1-17). Hoboken, New Jersey: John Wiley \& Sons, Inc.

Borman, W. C., \& Motowidlo, S. (1993). Expanding the criterion domain to include elements of contextual performance. In N. Schmitt \& W. C. Borman (Eds.), Personnel selection in organizations (pp. 71-98). San Francisco: Jossey-Bass.

Borman, W. C., \& Motowidlo, S. J. (1997). Task performance and contextual performance: The meaning for personnel selection research. Human performance, 10(2), 99-109.

Breaugh, J. A. (1999). Further investigation of the work autonomy scales: Two studies. Journal of Business and Psychology, 13(3), 357-373.

Campbell, J. P. (1990). Modeling the performance prediction problem in industrial and organizational psychology. In M. D. Dunnette \& L. M. Hough (Eds.), Handbook of industrial and organizational psychology (pp. 687-732). Palo Alto, CA: Consulting Psychologists Press.

Chen, J.-C., Silverthorne, C., \& Hung, J.-Y. (2006). Organization communication, job stress, organizational commitment, and job performance of accounting professionals in Taiwan and America. Leadership \& Organization Development Journal, 27(4), 242-249.

Chen, Y.-F. (2009). Job stress and performance: A study of police officers in central Taiwan. Social Behavior and Personality: an international journal, 37(10), 1341-1356.

Cho, T., \& Yoon, S. (2009). Human resource management, individualism-collectivism, and individual performance among public employees: A test of the main and moderating effects. The Korean Journal of Policy Studies, 23(2), 57-78.

Cohen, J. (1988). Statistical Power Analysis for the Behavioral Sciences (2nd ed.). Mahwah, NJ: Lawrence Erlbaum.

Cote, S., \& Miners, C. T. (2006). Emotional intelligence, cognitive intelligence, and job performance. Administrative Science Quarterly, 51(1), 1-28.

Crossman, A., \& Abou-Zaki, B. (2003). Job satisfaction and employee performance of Lebanese banking staff. Journal of Managerial Psychology, 18(4), 368-376.

Delery, J. E., \& Doty, D. H. (1996). Modes of theorizing in strategic human resource management: Tests of universalistic, contingency, and configurational performance predictions. Academy of Management Journal, 39(4), 802-835.

Demortier, A.-L., Delobbe, N., \& El Akremi, A. (2014). Opening the black box of hr practices performance relationship: Testing a three pathways AMO model. Academy of Management Annual Meeting Proceedings, 1201-1206. doi: 10.5465/AMBPP.2014.102

Den Hartog, D. N., Boon, C., Verburg, R. M., \& Croon, M. A. (2013). HRM, Communication, Satisfaction, and Perceived Performance A Cross-Level Test. Journal of management, 39(6), 1637 1665.

Dysvik, A., \& Kuvaas, B. (2008). The relationship between perceived training opportunities, work motivation and employee outcomes. International Journal of Training and Development, 12(3), $138-157$.

Eguchi, K. (2005). Job transfer and influence activities. Journal of Economic Behavior \& Organization, 56(2), 187-197.

Fluegge, E. R. (2008). Who put the fun in functional? Fun at work and its effects on job performance. (PhD Dissertation), University of Florida.

Gellatly, I. R., \& Irving, P. G. (2001). Personality, autonomy, and contextual performance of managers. Human performance, 14(3), 231-245.

Gong, Y., Chang, S., \& Cheung, S. Y. (2010). High performance work system and collective OCB: A collective social exchange perspective. Human Resource Management Journal, 20(2), 119-137.

Gray, J., \& Laidlaw, H. (2002). Insider perspectives on communication satisfaction. Australian Journal of Communication, 29(3), 111-124.

Griffin, M. A., Neal, A., \& Parker, S. K. (2007). A new model of work role performance: Positive behavior in uncertain and interdependent contexts. Academy of Management Journal, 50(2), 327347. 
Hackman, J. R., \& Oldham, G. R. (1975). Development of the job diagnostic survey. Journal of applied psychology, 60(2), 159-170.

Hair Jr, J. F., Hult, G. T. M., Ringle, C., \& Sarstedt, M. (2014). A primer on partial least squares structural equation modeling (PLS-SEM). london, UK: SAGE Publications, Incorporated.

Hosseini, S. M., Sourati, P., \& Kargar, M. (2015). A Survey of the Relationship between Job Rotation and job Performance of the Managers of Bank Meli of Gilan Province. Journal Of Applied Sciences Research, 11(1), 60-65.

Huang, T. C. (2015, 12-13 february). The effects of human resource management practice on employees' motivation and performance. Paper presented at the ICMLG2015-The 3rd International Conference on Management, Leadership and Governance: ICMLG2015, newtheland

Inyang, B. J., \& Akaegbu, J. B. (2014). Redefining the Role of the Human Resource Professional (HRP) in the Nigerian Public Service for Enhanced Performance. International Journal of Business Administration, 5(1), 90-98. doi: 10.5430/ijba.v5n1p90

Jagero, N., Komba, H. V., \& Mlingi, M. N. (2012). Relationship between on the Job Training and Employee's Performance in Courier Companies in Dar es Salaam, Tanzania. International Journal of Humanities \& Social Science.

Jorgensen, M., Davis, K., Kotowski, S., Aedla, P., \& Dunning, K. (2005). Characteristics of job rotation in the Midwest US manufacturing sector. Ergonomics, 48(15), 1721-1733.

Khalid, M. M., AbdulRehman, C., \& Ilyas, M. (2014). HRM Practices and Employee Performance in Public Sector Organizations in Pakistan: An Empirical study. International Journal of Management Sciences and Business Research, 3(2), 69-77.

Khan, F., Rasli, A. M., Yusoff, R. M., Ahmed, T., Abid ur Rehman, \& Khan, M. M. (2014). Job Rotation, Job Performance, Organizational Commitment: An Empirical Study On Bank Employees. Journal Of Management Info, 3(1), 33-46.

Khan, M. M., \& Jabbar, M. (2013). Determinants of Employees Performance in Corporate Sector: Case of an Emerging Market. Business and Management Research, 2(3), 25-32.

Kolz, A. R., Mcfarland, L. A., \& Silverman, S. B. (1998). Cognitive ability and job experience as predictors of work performance. The Journal of Psychology, 132(5), 539-548.

Koopmans, L., Bernaards, C., Hildebrandt, V., van Buuren, S., van der Beek, A. J., \& de Vet, H. C. (2012). Development of an individual work performance questionnaire. International Journal of Productivity and Performance Management, 62(1), 6-28.

Koopmans, L., Bernaards, C. M., Hildebrandt, V. H., Schaufeli, W. B., de Vet Henrica, C., \& van der Beek, A. J. (2011). Conceptual frameworks of individual work performance: a systematic review. Journal of Occupational and Environmental Medicine, 53(8), 856-866.

Kotur, B. R., \& Anbazhagan, S. (2014). Education and Work-Experience-Influence on the Performance. Journal of Business and Management, 16(5), 104-110.

Kumar, R. (2014). Impact of Emotional Intelligence on Employees' Performance: A Study of Employees Working in Himachal Pradesh University Shimla. Available at SSRN 2451027.

Kuvaas, B., \& Dysvik, A. (2010). Exploring alternative relationships between perceived investment in employee development, perceived supervisor support and employee outcomes. Human Resource Management Journal, 20(2), 138-156.

Lam, W., Chen, Z., \& Takeuchi, N. (2009). Perceived human resource management practices and intention to leave of employees: the mediating role of organizational citizenship behaviour in a SinoJapanese joint venture. International Journal of Human Resource Management, 20(11), 2250-2270. doi: 10.1080/09585190903239641

Langfred, C. W., \& Moye, N. A. (2004). Effects of task autonomy on performance: an extended model considering motivational, informational, and structural mechanisms. Journal of applied psychology, 89(6), 934-945.

Latham, G. P. (1988). Human Resource Training and Development. Annual review of psychology, 39(1), 545-582. doi: 10.1146/annurev.ps.39.020188.002553

Leković, B., \& Berber, N. (2014). The Relationship Between Communication Practice and Organizational Performances in Organizations from Europe. Industrija, 42(3), 101-114. 
Marwat, Z. A., Qureshi, T. M., \& Ramay, M. I. (2006). Impact of human resource management (HRM) practices on employees performance. International Journal.

Memari, N., Mahdieh, O., \& Marnani, A. B. (2013). The impact of Organizational Commitment on Employees Job Performance." A study of Meli bank". Interdisciplinary Journal of Contemporary Research in Business, 5(5), 164-171.

Motowidlo, S. J. (2003). Job performance. In I. B. Weiner (Ed.), Handbook of psychology (Vol. 12). New Jersey: John Wiley \& Sons Inc., Hoboken.

Motowidlo, S. J., \& Van Scotter, J. R. (1994). Evidence that task performance should be distinguished from contextual performance. Journal of applied psychology, 79(4), 475-480.

Muda, I., Rafiki, A., \& Harahap, M. R. (2014). Factors Influencing Employees’ Performance: A Study on the Islamic Banks in Indonesia. International Journal of Business and Social Science, 5(2), 73 80 .

Murphy, K. R. (1989). Is the relationship between cognitive ability and job performance stable over time? Human performance, 2(3), 183-200.

Nadarajah, S., Kadiresan, V., Kumar, R., Kamil, N. N. A., \& Yusoff, Y. M. (2012). The Relationship of HR Practices and Job Performance of Academicians towards Career Development in Malaysian Private Higher Institutions. Procedia-Social and Behavioral Sciences, 57, 102-118.

Nadarasa, T. (2013). The impact of perceived human resource practices on performance of the employees special reference to the telecommunication industry in jaffna district. Global journal of commerce \& management perspectives, 2(6), 72-77.

Obasanjo, O. (2003). Presedential speech at the inauguration ceremony of the new members of the national assembly, On 5th june, 2003. Abuja, Nigeria

Obisi, C., Uche, C. B. N., \& Ifekwem, N. E. (2010). Employee Compensation Management in Nigerian Organisations: Some Observations and Agenda for Research. Swiss Journal of Management \& Business Studies, 1(1), 23-32.

Onah, F. O. (2012). Engaging the challenges of human resources management in public organizations in Nigeria: Being text of the 65th Inaugural Lecture of University of Nigeria, Nsukka, Nigeria.

Perera, G. D. N., Khatibi, A., Navaratna, N., \& Chinna, K. (2014). Job satisfaction and job performance among factory employees in apparel sector. Asian journal of management sciences \& education, 3(1), 96-104.

Pushpakumari, M. (2008). The impact of job satisfaction on job performance: An empirical analysis. Paper presented at the City Forum.

Rashki, Z., Hasanqasemi, A., \& Mazidi, A. (2014). The study of job rotation and staff performance in customs organization of Golestan and Mazandaran Provinces. Kuwait Chapter of Arabian Journal of Business and Management Review, 3(7), 186-194.

Ringle, C., Wende, S., \& Will, A. (2005). Smart-PLS Version 2.0 M3. University of Hamburg.

Rothmann, S., \& Coetzer, E. (2003). The big five personality dimensions and job performance. $S A$ Journal of Industrial Psychology, 29(1), p. 68-74.

Safdar, R. (2011). HRM: Performance Relationship: Need for Further Development? International Journal of Public Administration, 34(13), 858-868.

Salisu, M. (2001). Incentive structure, civil service efficiency and the hidden economy in Nigeria: WIDER Discussion Papers//World Institute for Development Economics (UNU-WIDER).

Schuler, R. S., \& Jackson, S. E. (1987). Linking competitive strategies with human resource management practices. The Academy of Management Executive, 1(3), 207-219.

Shahzad, K., Bashir, S., \& Ramay, M. I. (2008). Impact of HR practices on perceived performance of university teachers in Pakistan. International review of business research papers, 4(2), 302-315.

Shooshtarian, Z., Ameli, F., \& Amini Lari, M. (2013). The Effect of Labor's Emotional Intelligence on Their Job Satisfaction, Job Performance and Commitment. Iranian Journal of Management Studies, 6(6), 27-43.

Sonnentag, S., \& Frese, M. (2002). Performance concepts and performance theory. Psychological management of individual performance, 23, 3-25. 
Suleiman, W. (2013). A Study of Causes of Poor Attitude to Work among workers of both Public and Private Sectors Organizations in Bauchi State-Nigeria. International Journal of Academic Research in Business and Social Sciences, 3(7), 143-152.

Sultana, A., Irum, S., Ahmed, K., \& Mehmood, N. (2012). Impact of training on employee performance: A study of telecommunication sector in Pakistan. Interdisciplinary Journal of Contemporary Research in Business, 4(6), 646-661.

Sun, L.-Y., Aryee, S., \& Law, K. S. (2007). High-performance human resource practices, citizenship behavior, and organizational performance: A relational perspective. Academy of Management Journal, 50(3), 558-577.

Susanty, A., Miradipta, R., \& Jie, F. (2013). Analysis of the effect of attitude toward works, organizational commitment, and job satisfaction, on employee's job performance. European Journal of Business and Social Sciences, 1(10), 15.

Tabiu, A., \& Nura, A. A. (2013). Assessing the effects of human resource management (HRM) practices on employee job performance: A study of usmanu danfodiyo university sokoto. Journal of Business Studies Quarterly, 5(2), 247-259.

Tarus, B. K. (2014). Effects of Job Rotation Strategy on High Performance Workplace, in Lake Victoria North Water Services Board, Kenya. International Journal of Business and Management, 9(11), 139 -146. doi: 10.5539/ijbm.v9n11p139

Tiwari, P. (2011). Impact of Selected HRM Practices on Perceived Employee Performance: An Empirical Study. Global Management Journal, 3(1/2), 37-43.

Tsui, A. S., Pearce, J. L., Porter, L. W., \& Tripoli, A. M. (1997). Alternative approaches to the employee-organization relationship: does investment in employees pay off? Academy of Management Journal, 40(5), 1089-1121.

Vlachos, I. P. (2009). High-performance workplace practices for Greek companies. EuroMed Journal of Business, 4(1), 21-39.

Wright, T. A., Cropanzano, R., \& Bonett, D. G. (2007). The moderating role of employee positive well being on the relation between job satisfaction and job performance. Journal of occupational health psychology, 12(2), 93-104.

Yozgat, U., Yurtkoru, S., \& Bilginoğlu, E. (2013). Job stress and job performance among employees in public sector in Istanbul: Examining the moderating role of emotional intelligence. ProcediaSocial and Behavioral Sciences, 75, 518-524.

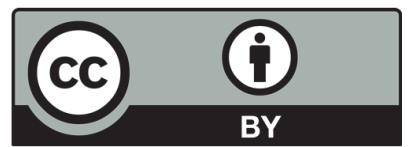

(C) 2016 by the authors; licensee Growing Science, Canada. This is an open access article distributed under the terms and conditions of the Creative Commons Attribution (CC-BY) license (http://creativecommons.org/licenses/by/4.0/). 